\title{
OBITUARY.
}

\section{WILFRID DE FONVIELLE.}

Wilfrid de Fonvielle died on the 29th of April, at Paris, aged 88 years. $\mathrm{He}$ was one of the fast dwindling band of early aeronautical pioneers, who have had the felicity of seeing their aspirations of so many years take concrete form and commence to become part of the every day life of the world.

The part which he played in the long campaign of argument and experiment that was to vindicate the claims of those who claimed flight to be possible was characteristically energetic, and his output of articles and books was tremendous. A life so full of incident cannot be adequately summed up in a few words. Deported at the time of the Coup d'Etat of $185^{2}$ to Algeria, for his Republican sympathies, he afterwards went to London and studied at the Royal Institution. Afterwards returning to France he occupied himself with electricity for some years. In the war of $1870-7 \mathrm{I}$ his aeronautical studies stood France in good stead. In company with Mons. Tissandier he offered at the outset to accompany the army of the Rhine with captive balloons. It is said that this offer was not even acknowledged by the Powers that were, but it was not long before the beleaguerment of Paris by the victorious Germans made the balloon the only means of communication with the outside world. A balloon service was formed by Mons. de Fonvielle and others. He escaped from Paris in a balloon at ro a.m. on the 24th November, 1870 , and $4 \frac{1}{4}$ hours later landed at Louvain in Belgium. The balloon service which he helped to found was most successful, as is well known, and it is small wonder that with such an example always in his mind Mons. de Fonvielle remained an enthusiastic partisan of the "lighter-than-air" to the day of his death.

He was one of the moving spirits of La Société Francaise de Navigation Aérienne, of which he was an ex-President, and a Membre d'honneur of the Aéro Club de France. He was also an enthusiastic member of the Société Astronomique de France.

In Igor Mons. de Fonvielle came to London at the invitation of the Aeronautical Society to deliver a lecture on "Aeronautics in France," and it is interesting to remember in passing that at that time "L'Entente Cordiale" had not yet come into being; in fact, owing to the Boer War the relations between the two countries were not of the pleasantest. However, science knows no frontiers and the visit was most successful, as may be seen by referring to the report in the Aëronautical Journal, July, Igor. Mons. de Fonvielle was made an Honorary Member of the Society, thus signalising the friendly relations between the French and English societies that have always existed.

At the Council Meeting of the Ioth June, 1914, the following resolution was passed:-

"That the Council of the Aeronautical Society of Great Britain has learnt with great regret of the death of Mons. Wilfrid de Fonvielle, an Honorary Member of the Society since rgor, and begs to tender to his family and to his colleagues of the Société Francaise de Navigation Aérienne and l'Aéro Club de France, sincerest sympathy in their great loss."

\section{GUSTAV HAMEL.}

Born June 25, 1889. Lost at Sea, May 23, 1914.

By general consent, the loss of Gustav Hamel is the biggest personal loss British aviation has sustained. The Admiralty signalised this in a very uncommon 
way, on the abandonment of the search for any trace of. Hamel in the Channel, by issuing an announcement, in the course of which they said :-

He was without question the foremost exponent in these islands of an art whose military consequence is continually increasing. His qualities of daring, skill, resource, and modesty merited the respect of those who pursue the profession of arms.

The King and Queen wrote to the bereaved father a letter, in which their Majesties said they knew Gustav Hamel personally,

and were struck by the skill, courage, and mastery with which he controlled the aeroplane, no less than by his modest and unassuming bearing.

He was mourned as few have been; and it is but right that, in placing a brief account of his careei upon record, the reasons for this should be analysed.

Gustav Hamei never sought the popularity he won. He never resorted to aerodrome affectations, which are so painfully obvious in some fliers. Trying to solve the reason for his success, a mutual friend once said to me: "It is because he is artless. The public are so thoroughly weary of the methods of certain men that they give all their support to the man who does not stoop to them." No doubt this counted; but then there are, fortunately, many aviators who do not resort to the common tricks of the publicity seeker, so that the explanation is inadequate. Hamel was seldom interviewed for the newspapers. His sole appeal to the public, apart from his flying, was his book written in collaboration with myself.

As he appeared to the public, who saw him flying at Hendon and elsewhere, he was unquestionably a more brilliant pilot than any other; but, after all, the actual difference between him and many another was not enormous, and that little difference surely does not account for the very much higher place he had in their regard. Certainly he gained a reputation for punctuality, and he always endeavoured to give rather more than was expected of him; and this counts for a good deal. This is, indeed, admirable, especially in a man who is. known to be popular in the "higher circles," as Hamel was. But the public also loved his youthfulness, and were taken by his unaffected manner and his " looks.". He looked, and he was, clean. He was just a public school boy. He was liked by men who were supposed to be his rivals; and never was there a brilliant flier who was less the object of professional jealousy.

To pass from the lovable personality of the man to the work he did; I count it, if anything, in his favour that he broke no world's records. He could have flown the fastest death-trap of an aeroplane ever made; but I rather doubt if he could have beateri the duration record, or the altitude record of 20,000 feet or so. The latter, possibly. At any rate, these things never appealed to him : he was not deeply impressed with their importance. Yet was he master of his art, and cared little how hard it blew or rained provided he could get an occasional glimpse of earth. For four years he was ever on the wing, and he must have flown tens of thousands of miles. He could, aerially, read much of England and France like a book.

It were almost idle to speculate on the cause of his disappearance, but I decline to believe that he was guilty of very bad judgment in attempting to cross the Channel even in the bad conditions that prevailed on May 23. That he madea mistake somewhere is undeniable. But he knew the risks well, and had overcome treacherous conditions again and again. His machine was so fast that the crossing: should have taken no more than twenty minutes. It had served him well all day, and he had had a foretaste of contrary winds : he had not been lulled into a false sense of security. For these reasons we must acquit him of any greater folly than that inherent in essaying the crossing in any circumstances on a machine that will not float well. He had often told me that it was a risky thing to do; 
and yet we find him doing it on May 23. If one of us; his personal friends, had been there with him, he might have been induced to delay the crossing. But confidently, bravely, alone he made his last ascent, gazed around and below at the chequered plains of France dimly seen through the mist, at thick clouds driving up Channel and hiding it; and he estimated the conditions and the risks, and headed towards England.

To sum up Hamel's work in a sentence, it may be said that he advanced the art of flying yenerally, and in certain quite definite details. It was characteristic of him that, although not the first to "loop the loop," when he did that feat it was on a standard machine of high power, and, in its way, a very definite piece of pioneering. And when he did "loop the loop" it was with a mastery that eclipsed most other fliers. His side overturns and his tail-slides were astonishing. In all these things he was adjudged the equal of Garros. But far more than in feats of this kind did his service to aviation consist. And it is a splendid consolation, ncw, that he was able, before he passed from our ken, to place a good deal of the experience that he had won in peril from the air upon record for the benefit of other fliers.

It came as a surprise to a great many, even of his friends, that Hamel, who talked so little and never expatiated on the scientific aspects of flying, nevertheless condescended to book-writing. When I proposed the matter to him in May, 1913, the welcomed the idea enthusiastically. So we set to work. He had no experience of book-compilation, but here my training, such as it is, came in, with the advantage that I knew, at any rate, the rudiments of aeronautics and of the practical art of flying. I was able to draw up a fairly workable scheme and obtain and classify a good deal of the tremendous amount of detailed knowledge that Hamel had accumulated, and over which he cogitated and pondered far more than people who only saw him fly could possibly imagine. I could never suggest a point to him that failed to draw some valuable contribution. A great deal of his experience is that of others, of course, but the fact that many very experienced aviators have told me that they find much to learn in the book proves how very necessary was this first really serious work dealing with practical piloting. It was nothing like the book we mapped out, but no book ever is. But its reception by all the reviewers, and especially by those who are competent from an expert point of view, showed Hamel, it is pleasant to know in time, that he had done well. We had an ambitious programme of flying experiments to carry out for a further work; but all this, alas! is now abandoned.

In the preparation of the book Hamel worked hard. Chiefly it was by means of long consultations together, afterwards materialised in manuscript, which he and $I$ read together. On a number of subjects he wrote notes, some detailed, others sketchy, for me to elaborate. I should like you to leave off reading this with a glimpse of Hamel, a man made much of by society, and enjoying that side of life in youthful good spirits, but spending happy, satisfying hours hard at work on the book.

It was Hamel's scheme for crossing the Atlantic that almost shook even smy scepticism on this subject. I really think, with the forethought and the elaborate organisation he was putting into it, that he might have been the first ito fly across "the herring pond." Contrary to the belief of many who did not know him, he was going to leave very little indeed to chance. It was a sound scheme; but of course it would not have ushered in a weekly aeroplane transAtlantic service, any more than will any other scheme that may happen to succeed.

Hamel had yet to do much for flying. Let no man say his work, great as it was, had finished. There were matters toward beside which even that which the did would fade into comparative insignificance. 